研究

\title{
油圧ならい装囯の温度ドリフト・
}

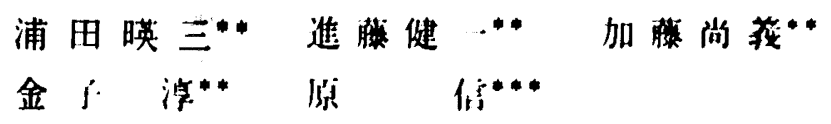

\section{Thermal Drift of Hydraulic Copying System}

\author{
Eizo Urata, Makoto Hara, Kenichi Shindo, Naoyoshi Kato, Atsushi Kaneko
}

Complaints arose from some of the working fields that workpieces produced by a hydraulic copying system show intolerable deviation in their dimensions.

In this paper the authors firstly revealed that such a deviation in dimensions came from thermal expansion of structural elements of the hydraulic copying system. And the major part of the thermal drift is caused by the temperature variation of hydraulic fluid.

Secondary experimental result and theoretical result of the drift were compared and two methods to reduce the thermal drift were proposed; the first method is to arrange tool tip and stylus tip of pilot valve in the same plane normal to the copying direction; the second method is to place an alminium subplate between the copying cylinder and the pilot valve. Effect of these two methods were verified in experiments.

\section{1. はしがき}

油圧ならい装目の主要な用途は，同一寸法の紫品を 数多く加工することである. 油圧ならい装目を使用し て加工を行った製品の寸法の誤差の中に，統計的なば らつき以外のものがある。たとえば朝，刃物の位骨を 設定して，同一の丸物の旋削を始めると，1時間はど で，加工物の直径が $0.1 \mathrm{~m}$ ठ小さくなったという事例 や，長い軸物の旋削時们周方向のすじを生じたり， テーパを生じる事例などがれである。

并の不感帯ヤシルティンク，部材の网性不足などだ けでててうした誤差をすへて説明するてとは無理があ ると思われた。そてでシルティングや不感帯，部材刪

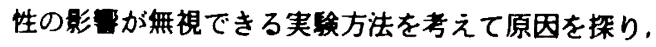
ならい装置各部の熱膨張が最大の誤差要因であるとと

* 昭和59年12月18日 原稿受付

** 神奈川大学工学部機械工学科

***八千代田工業株式会社
をつきとめた.

\section{2. トリリフの原因を求める実涻}

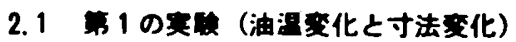

良く仕上げた油圧ならい装䨿の㔖き当て精度（㔖き

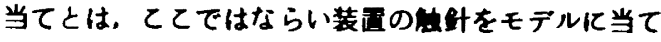
て、装置を停止させるてとを意味する）は， $\pm 2 \mu \mathrm{m}$ 以下になる．それが50um近くのの寸法差を生み出 すことは，当初は供常なととと思われた.そてでFig. 1 のように雪磁石を案内并に取りつけてスプールを制海

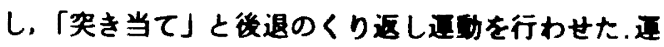

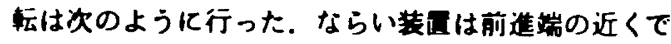
突き当てによって停止し，粎 8.5 秒停止後に後退通跏 し，後退端でる約 8.5 秒停止した後，前進運動に移ろ。 前後進とも所要時間は約 1.5 秒なので。1サイクルは 約20秒である．停止時間は端部のリミットスイッチと タイマによって調整した。

ならい装置各部の温度は，測定部に直径 $3 \mathrm{~mm}$ ，深さ 4 皿の小孔を穿ち。サーミスタ温度計を埋めて测定し 
た.

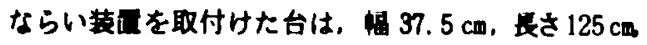
高さ55cmの籍铁製定盤である. 同じ定盤上にダイヤル ゲージを治具を用いて固定し，変位测定を行った．各

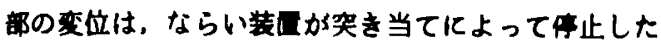
ときに毎回邻定し，象止㭙のダイヤルゲーシ指示偣の 变化を誖みとって行くととにした。

油压ならい装目とその制期回路をFig. 2に示す。

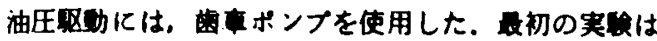
フィールドでの使用状慗をシミュレートする劃味で, Fig. 2 中の目度制散回路を作物させずに行った。
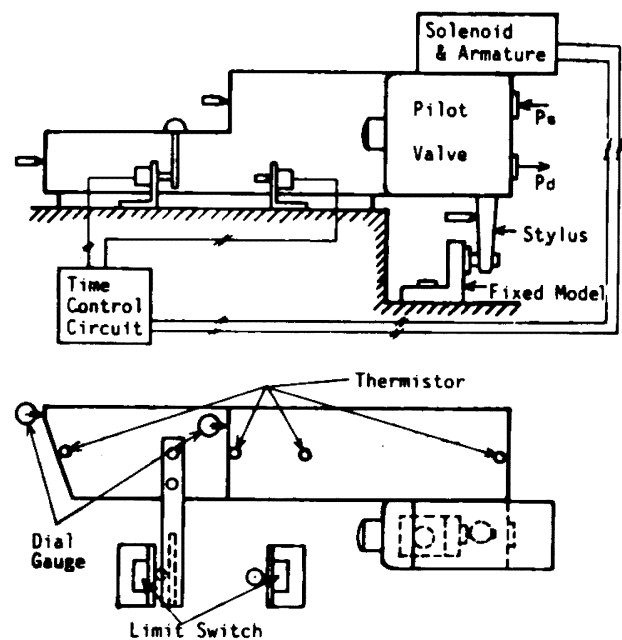

Fig. 1 Copying System and Measuring Positions

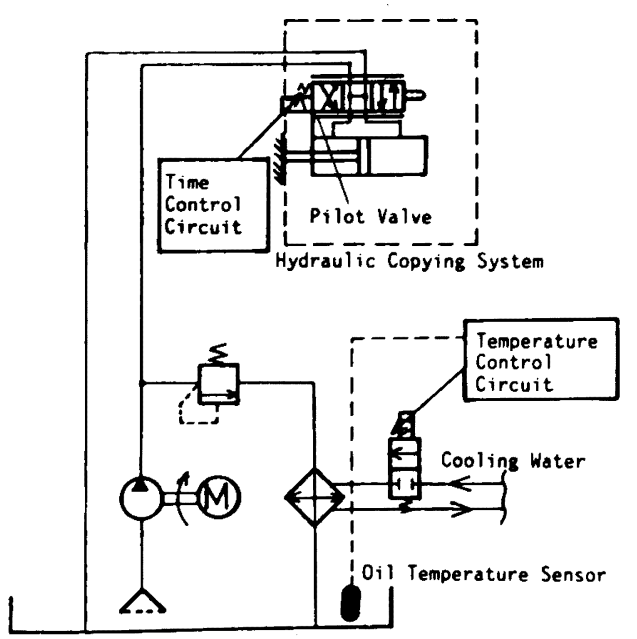

Fig.2 Experimental Rig
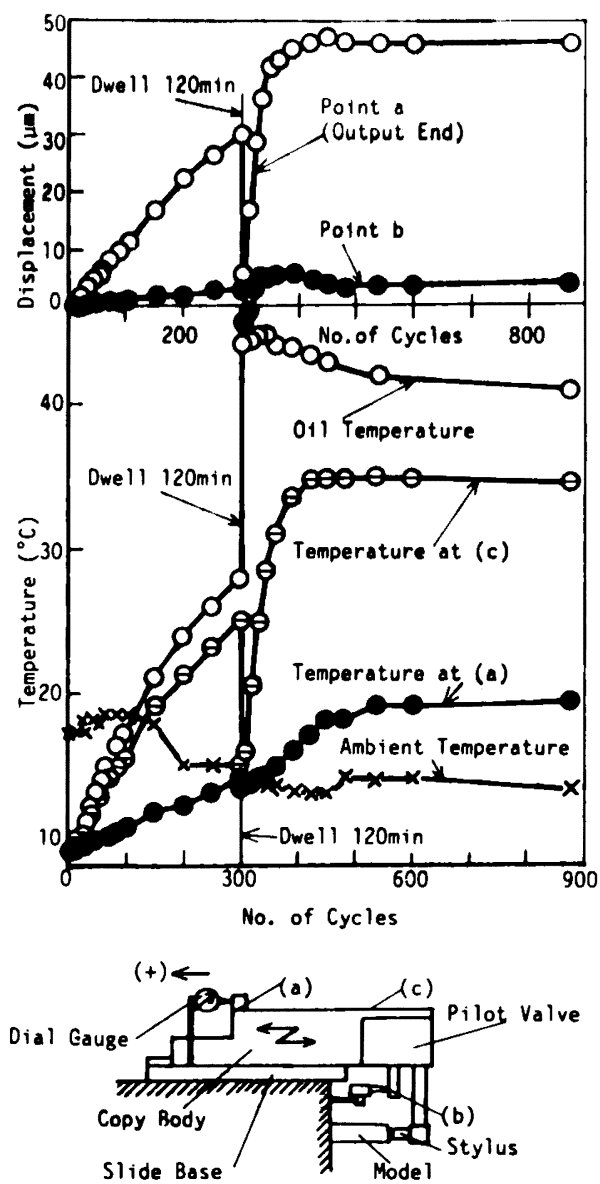

Fig.3 Temperature and Displacement of Hydraulic Copying System

冬朝の朝の，いわゆるcold start を行ったときの実 倹例をFig. 3に示す，正枟開始後，始めの 300 サイク ルが約 $12 / 3$ 時間にあたる. この間に油温は約 $10^{\circ}$ Cから $28^{\circ} \mathrm{C}$ な゙上昇し，乙れとほぼ類似の曲線を描いて，装

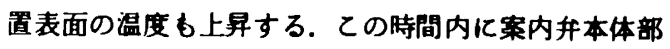
(Fig. 3 下図の b点) は約 $2 \mu \mathrm{m}$ 程度のドリフトを生じ ていろのに対し，刃物台部分，すなわちならい装目の 出力部（a 点）は約 $30 \mu \mathrm{m}$ 定常的に前進した.

この後，ならい装固の通勒を停止し，ポンプのみを 約 2 時間通転した. このポンプ更転により，タンクの

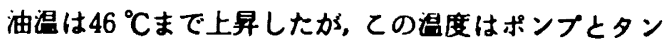
クとの組合せでの和和温度である.ならい装異が停止 しているために油の流れも止まっていろので，装畳各 部の温度は室温に向かって低下し，同時に出力端の前 進量も $4 \mu \mathrm{m}$ まで低下した。 


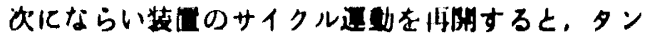
クの油温は少しづつ低下し，終的には $41^{\circ} \mathrm{C}$ 惊度とな

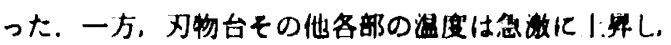

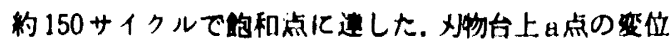

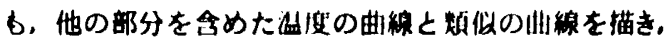
サイクル回数 150 程度で做 $46 \mu \mathrm{m}$ を蚛蹋した，策 内并本体部は $1 \mu \mathrm{m}$ 程度のドリフトを生じただけであ った。同棌の実馀はくり返し多数の目数をかけで彳亍

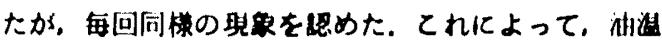
か出力端ドリフトの上要な原因であると考えるに片っ た.

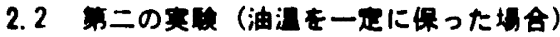

油温と装罾各部のドリフトの關を知るために。油

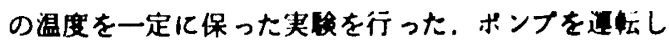
温度制御装泪によって温度を設定した後にならい装 而のサイクル通的を始めた。温度投定は $30^{\circ} \mathrm{C}, 35^{\circ} \mathrm{C}$.

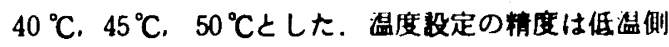
では土 $1{ }^{\circ} \mathrm{C}, 45^{\circ} \mathrm{C}$ び50 ${ }^{\circ} \mathrm{C}$ で結果的に士 $2{ }^{\circ} \mathrm{C}$ とっ たか，定常状悲でははとんど变轩しなくなる．乙の寒

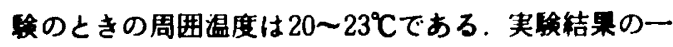
例をFig. 4 亿示す.
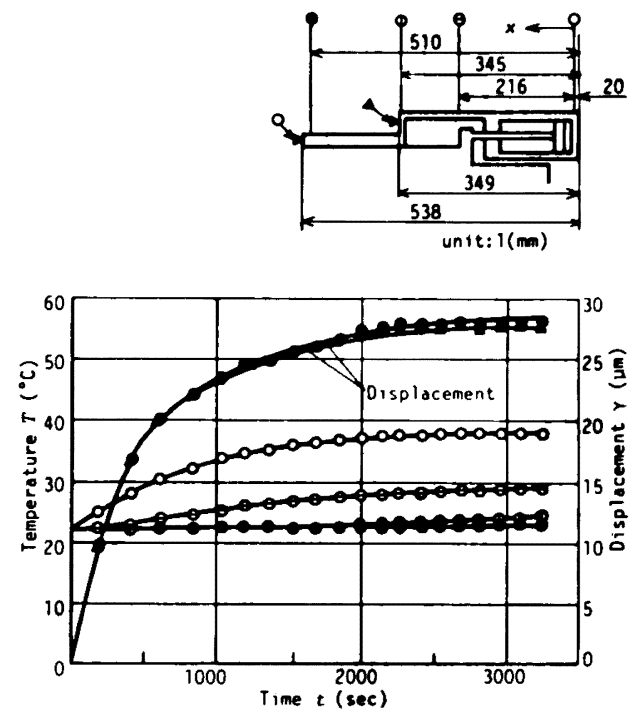

Fig.4 Typical Measured Results of Temperatures and Displacements (oil temperature: $40^{\circ} \mathrm{C}$ )

設定温度と出力端近傍の 2 位置 $(x=325 \mathrm{~mm}$ 及 2518 m）の変位量の最終値との関係をFig.5 亿示す.Fig. 5 亿おいて，xはシリンタカバー面からの距離（Fig. 4. 6 参照), $r$.は变位量。 $T o$ は油温, $T i$ は初期温度 （ただしての場合は周冊温度と一致させておる）であ

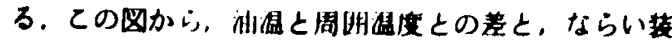
端幽力端のドリフトか，比していることかかかる。

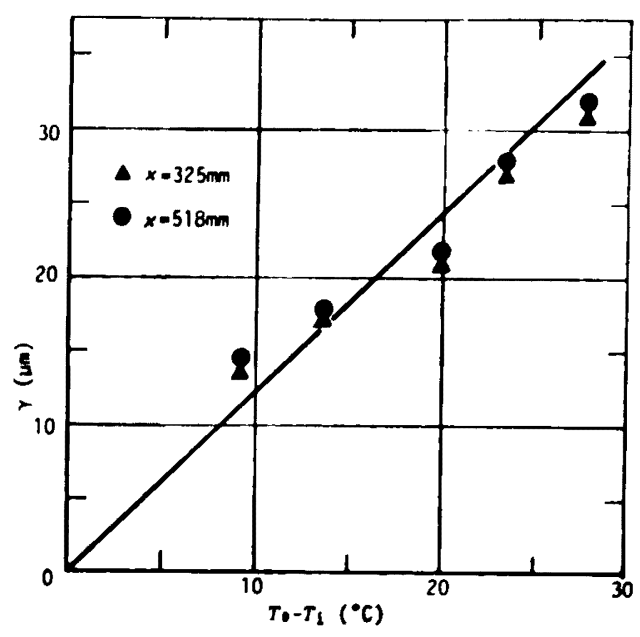

Fig. 5 Relation between Displacement and Temperature ( $x$ : distance from head end of cylinder, see also Fig.6)

\section{3. 温度分布及ひトリリトの計算}

油圧ならい装ででは、シリンタに海入した高目の神

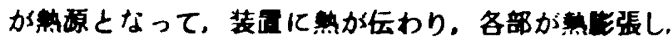
その結果が出力端位目のドリフトとして银されるて とか，前章の実臤で明らかてされた。整㱆張以外のト リフト要因か存在しても，通常の条件下では酸小であ

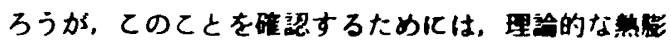
張量と実段值とを比校する必要がある.

理論計算は次のように行った。
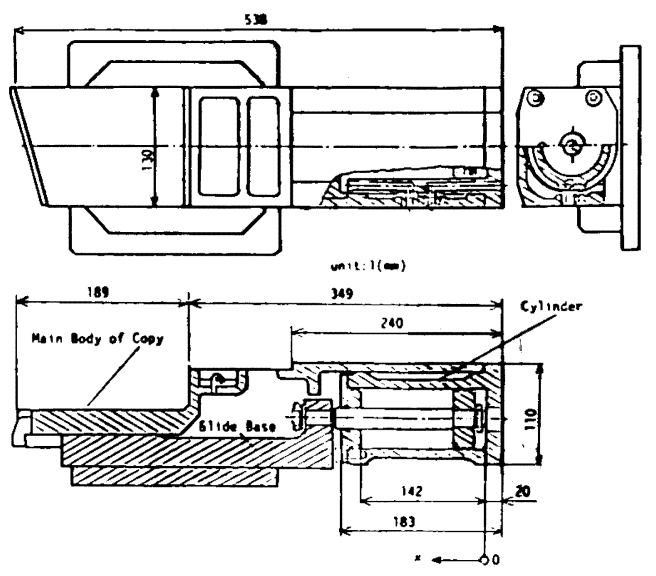

Fig.6 Structure and Dimensions of Copying System 


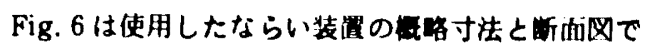
ある. この槽造から，シリンダ内の油の业は，シリン タのヘッドカバーから，ならい装目枠梢造に伝覃する ઢのか，大部分を占めることかかかる。をとでへッド カパー内面部が一定泪度を保ち，ここから装目各部に 整が流れるすのとして各部の泪度を求め，それによっ て服終的な出力端变位を計策してみろ，ての场合，林 棈造の断面程や周囲長さが座標によって果なる一次元 熱伝严を考えることにする，座到方向 $x$ と原点はFig. 6中に示してある.

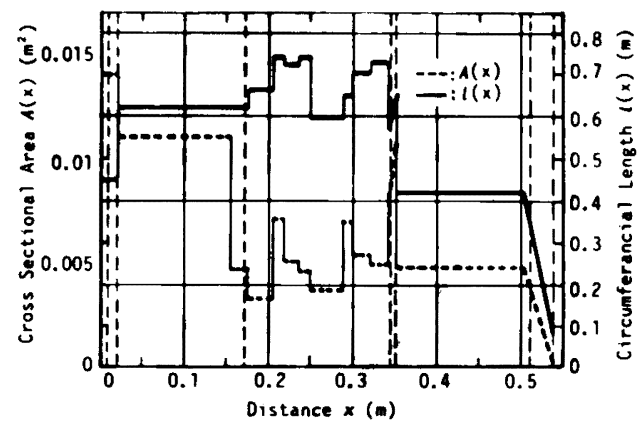

Fig.7 Dimension of Main Body of Copy

策伝草方程式は

$$
\frac{\partial T}{\partial t}=\frac{\lambda}{\rho C} \frac{\partial^{2} T}{\partial x^{2}}-\frac{h}{\rho C} \frac{l}{A}\left(T-T_{a}\right)
$$

$T$ : 温度 $\left({ }^{\circ} \mathrm{C}\right), T_{a}$ : 周囲温度 $\left({ }^{\circ} \mathrm{C}\right), t:$ : 時間 $(s)$, $h$ : 熱伝達率 $\left(W / \mathrm{m}^{2} K\right) ， \rho$ : 檴造材料密度 $(\mathrm{kg} /$

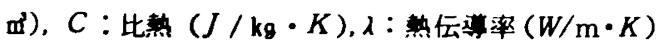

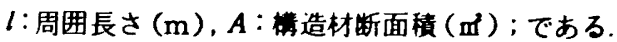

上記諸量のうち， $h, l, A$ はxの惪によって異る。 xに対するし，Aの分布は图面により求的てとがで き，Fig.7のようになる.l，Aはxの区間毎に一定 值をとっている部分がほとんどなので， $， A$ は一定 とした一次元熱伝尉問題の解を接続して，Tの分布を 求めることができる. 温度分布が求められれば，任意 点の熱膨張による変位量 $r(x)$ は，

$$
r(x)=\int_{x_{0}}^{x} \varepsilon\left(T-T_{i}\right) d x
$$

により求めることができる.ただし $\varepsilon$ は梇造材料の線 膨張係数， $x_{0}$ は变位原点で，触針先端住対応する位置 の座標值である.

式(1)の定常解をまず求める.

$T(x, t)=T_{\infty}(x)+T_{V}(x, t)$ とおくと,

$$
\frac{d^{2} T_{\infty}}{d x^{2}}-\frac{H l}{x A}\left(T_{-}-T_{a}\right)=0,
$$

たたし $H=h / \rho C, \boldsymbol{x}=\lambda / \rho C$ である，

区成) $x_{n-1} \leqq x<x_{n} \quad(n=1,2, \cdots, N)$ ととA

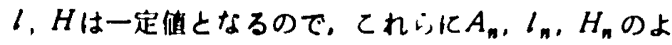
うに添字をつけることにすると，n番目の区咸に対し，

$$
\begin{aligned}
& T_{n}(x)=\alpha_{n} \cdot B_{n} x+\beta_{n} e^{-B_{n} x} \\
& B_{n}^{2}=\frac{l_{n} H_{n}}{\kappa A_{n}}=\frac{h_{n} l_{n}}{\lambda A_{n}}
\end{aligned}
$$

となる．ただし $\alpha_{n} ， \beta_{n}$ は次の境界条件により定める.

$$
x=0 \text { では }
$$$$
T_{1}(0)=T_{0}
$$

中間点 $x_{n}(1 \leqq n \leqq N-1)$ では

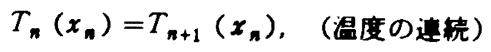

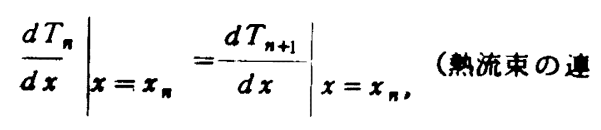

ならい装圈の端点 $x_{N}=L$ では

$$
\left.\frac{d T_{N}}{d x}\right|_{x=L}=0
$$

式(7)〜 00は $\alpha_{n}, \beta_{n}(n=1,2, \cdots \cdots, N)$ 亿関す ろ2N元速立方程式で，乙れを解いて $\alpha_{n} ， \beta_{n}$ を 求めろ. Fig. 7 の装圈の場合は $N=14$ であろ.

㙓伝達率は，空気のみにふれている部分と，固定台 にふれている部分とでは異なる，空気のみにふれてい ろ部分では $h \div 3.4 \mathrm{~W} / \mathrm{m}^{\circ} \cdot K$ と，通常の空気中放

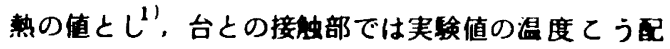
から求めたところ，設定油温により異るが， $h^{\prime}=27 \sim$ $45 W / \mathrm{m}^{2} \cdot K$ の值となった，温度分布の実測值と， $h^{\prime}$ をパラメータとした理論値をFig. 8 亿示す. 図の样袖 は無次元化した温度差で，

$$
T^{*}=\left(T_{\infty}(x)-T_{a}\right) /\left(T_{0}-T_{a}\right) \quad \cdots \cdots \text { (11) }
$$

横軸は無次元化した長さ $x / L$ である. 困中に示した 実鞈点は，2.2で述べた，油温一定のもとでの檤であ ろ. 定常温度分布は前記の計算法をとれば，各部分の 测定値をよく説明するととがわかる.

しかしての方法の計算では多元連立方程式を解く必 要があり，さらに非定常解を求める場合には，各区間 毎に多数の固有関数を計算することになり，計算量が ばく大になる。そてで精度を多少盖性にするが，次の ような近似温度分布を求める.

まず,ならい装置の断面形分布は複雑なので, これ 


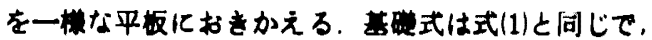
中间の境界条件(8)，(9)加俆去される，乙の近似旪策で は $A / l=$ 一定， $h=h_{m}=$ 一定と仮定する. $h_{m}$ の位

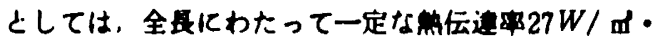
Kをとる.

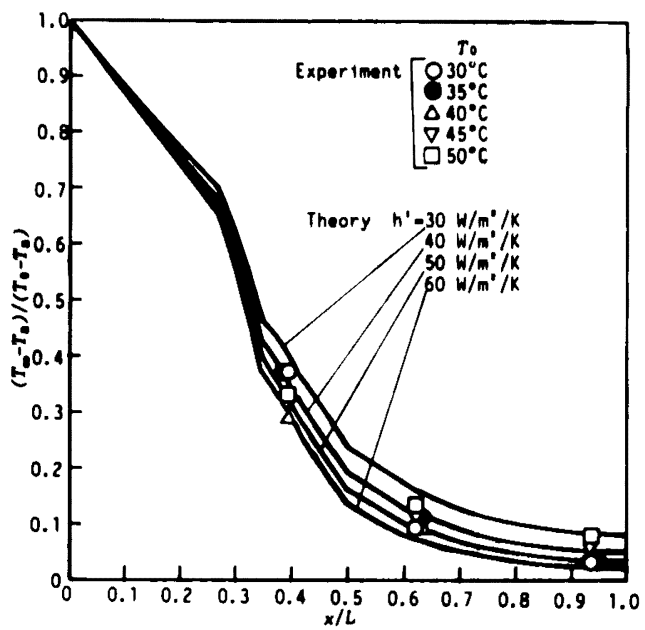

Fig.8 Steady Temperature Distribution

この数値は次のような考方方で定めた．Fig. 8 によ ると，取付台との接部では $\boldsymbol{h}^{\prime}=40 \mathrm{~W} / \mathrm{m} \cdot K$ 加通 当である. 図6の寸法加ら，取付部と接触している長 さは 349+189-183=355（ロ）であるか，往復连轩 するので，常時接触部は $305 \mathrm{~mm}$ ，往復速娌によって台

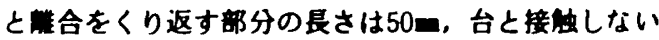
部分の長さは、ヘッドカパー厚さを除いて 163 ロで

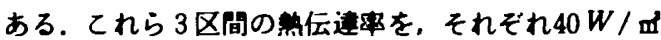
$K ，(1 / 2)(40+3.4) W / \mathrm{m}^{2} K$ ，及ひ3.4W/ ơ $K$ とし て平均值を求めると，

$$
\begin{aligned}
h_{m} & =\frac{40 \times 305+21.7 \times 50+163 \times 3.4}{538-20} \mathrm{~W} / \mathrm{m} K \\
& \doteqdot 27 W / \text { แ } K \text { である. }
\end{aligned}
$$

$A / l$ は次式によって求める.

$$
\frac{A}{l}=\frac{1}{L} \sum_{n=1}^{N} \frac{A_{n}}{l_{n}} x_{n}
$$

このように単純化を行えば，定常温度分布は2

$$
\left.\begin{array}{c}
\frac{T_{\infty}(x)-T_{i}}{T_{0}-T_{i}}=\cosh (\eta x)-\tanh (\eta L) \sinh (\eta x) \\
\eta=\sqrt{h_{m} l / \lambda A}
\end{array}\right\}
$$

$$
\left.\begin{array}{l}
T_{v}(x, t)=\sum_{n=1}^{\infty} C_{n} e^{-\mu_{n} t} \sin \left(\nu_{n} x\right) \\
\mu_{n}=H+\pi \nu_{n}^{2}, \quad \nu_{n}=\pi(2 N-1) / L, \\
C_{n}=2 \nu_{n}^{2}\left(T_{i}-T_{0}\right) /\left(\pi^{2}+\nu_{n}^{2}\right) \quad(n=1,2, \cdots)
\end{array}\right\}
$$

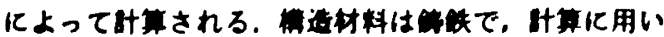
た定数は， $\rho=7.83 \times 10^{3} \mathrm{~kg} / \mathrm{mf}, C=465 \mathrm{~J} / \mathrm{kg} \cdot K$ ， $\lambda=54 \mathrm{~W} / \mathrm{m} \cdot K, \quad \mathrm{e}=1.05 \times 1 \sigma^{\circ} / K$ てある. $こ$

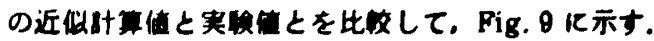

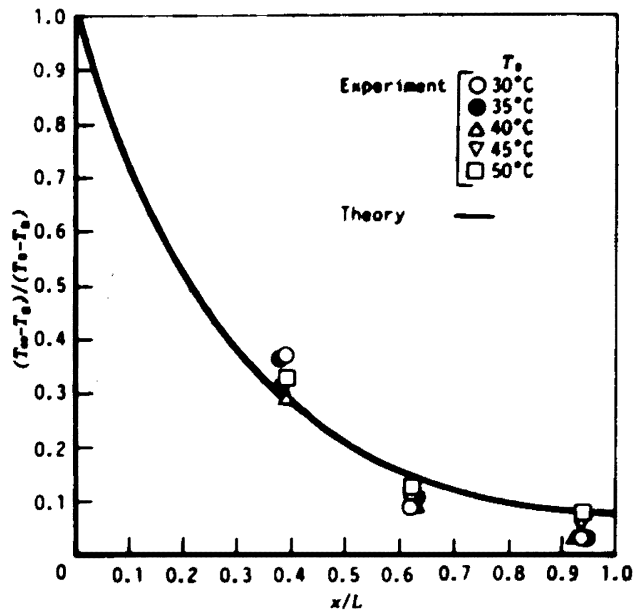

Fig.9 Simplified Theory for Temperature Distribution

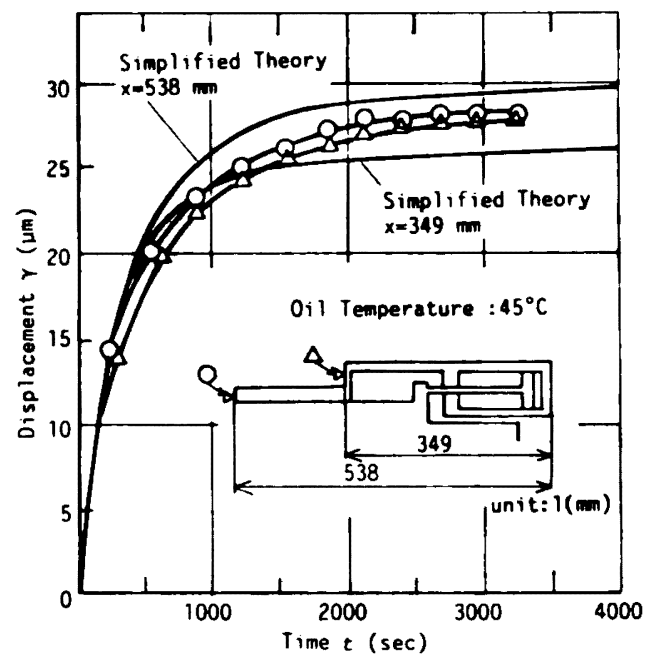

Fig.10 Transient Displacement

となる．また非定常温度 $T_{V}(x, t)$ は， 
Fig. 10 は $T_{i}=T_{a}=20^{\circ} \mathrm{C}, T_{0}=45^{\circ} \mathrm{C}$ の谒合の变位期の ドリフトを。式(2)によって呇めたののである。近似理

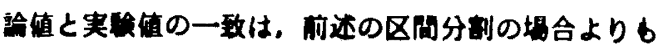

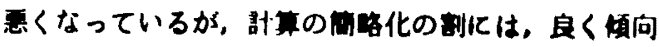
を表しており，実用的といえよう。

\section{4. ドリフトの防止}

油压ならい装四の寸法や取付状急からかれは，装而

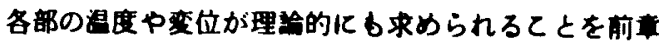
で示した。寒用上は出力妾位にドリフトを生じないて とが監くまれる。

Fig.5に示したととからかかるように，油温か室温 に等しくでれれは，相度による出力端ドリフトは消就 する. 実际には室目 +5 C程度です良い。しかし沮度 管理をそれはど能しく行うことは不释清である。

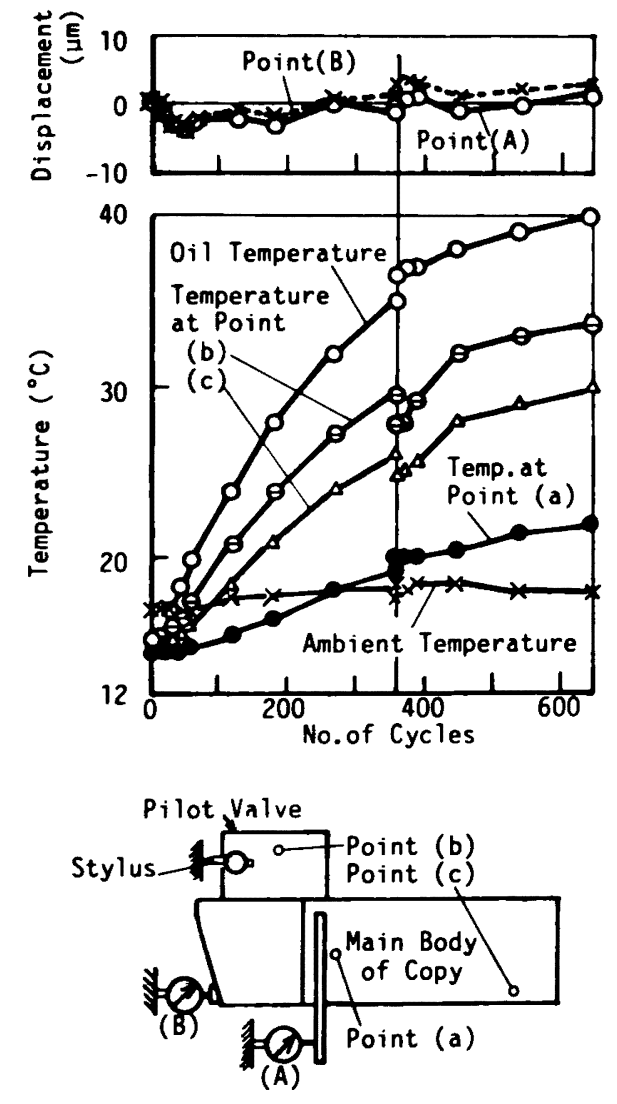

Fig.11 Effect of Pilot Valve Position

温度上昇による伸びは，熱䃇とみなされる，シリン

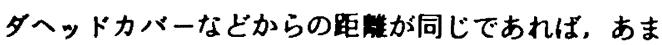
り大きな差はない（ただし同一材料，同一製伝達率が 前提)．したがって，案内并の触針先端が出力端と同

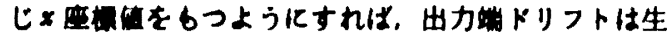
じなくなると费えられる。 このととを立证するために，

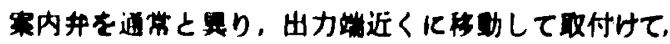
变位ドリフトを溂定した。刺定結果はFig.11に示すよ

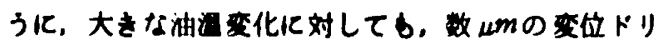
フトを生じるに留まった。

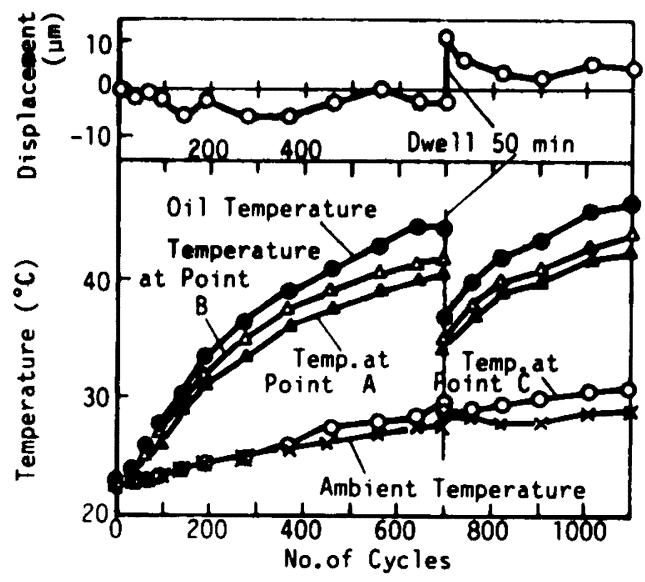

Fig.12(a) Effect of Aluminium Subplate

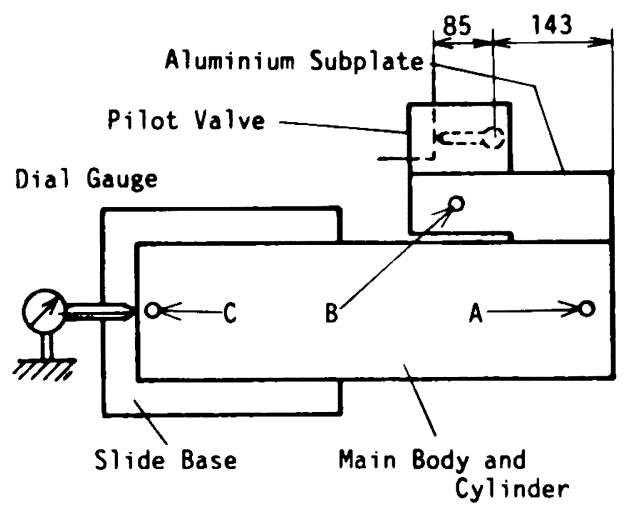

Fig.12(b) Subplate in Copying System

上記の方法は有奻であるてとは確かめたが，実察の 機械の目贯としては，不便になる場合がある，案内井 をもう少し後退させた位貫に取付け，なおかつドリフ 卜をおさえる方法として，整㱆張率の大きな材料を使 うことを考えた。 アルミニウムのように線膨張係数の 大きな材料で作ったサププレートを、シリンタと案内 并の間化介在させ，短い距離で長い前進吾加得られる ようにする．すなわちシリンダヘッドカバーからの距 離が短くなる分を線膨張係数を大きくするてとで㭪う. 
Fig.12はアルミニウムサフブレートを作って实谼を 行った結果である. この手法の奻果す，Fig. 3 と比校 すれば明らかである。.Fig.12の結果とFig.11の結果を 比へろと、サププレート方式の方が劣るように見える。 サププレートの寸法や取付方法は実䀧的に战行すれは 良の寸法等が定めうると考えている。

\section{5. むすひ}

正常な油压ならい装像において，大きな出力端变位 路差を生じるととがあると知り，その原肉か油湓变化

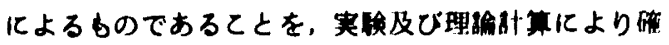
かめた.

变位䟚差を抑制するために，油の温度を宣温近くに 保持することは，経斎的に不利である，そこで対策と
して，察内䄯位四の出力端近くへの取付位目变更，及 びフルミニウムサフフフレートを介在させる，の 2 万法

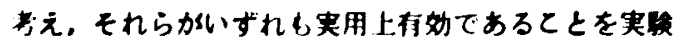
的汇碚かめた。

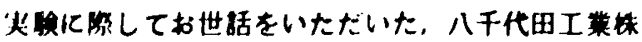
式会社に厚く稉礼申し上げる。

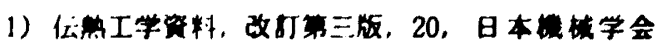
( 1977 ).

2) J.P. Holman (平田是比)，伝等工(上),86 丸普 (1982). 